\title{
The complexity of barriers to biogas digester dissemination in Indonesia: challenges for agriculture waste management
}

\author{
Ibnu Budiman ${ }^{1,2}$ (D) \\ Received: 7 January 2021 / Accepted: 14 June 2021 / Published online: 7 July 2021 \\ (c) The Author(s) 2021
}

\begin{abstract}
In the global south, the use of firewood and LPG as dominant energy sources for cooking contributes to socio-ecological issues. Alternatively, biogas is considered a clean energy source generated from organic waste. However, in Indonesia, until 2018, only less than $2 \%$ of households utilized biogas for cooking fuel. This research aims to explore the landscape of biogas governance in Indonesia, its fragmentation, and its relation with biodigester dissemination. This study found that there is fragmentation within small-medium scale national biogas programs in Indonesia. Seven national government biogas programs have similar governance arrangements and characteristics; scattered in different departments within the ministry, using the grant approach with two main vendors, often overlapping with local government programs, and not providing proper monitoring and evaluation mechanism, as well as proper training for users. Meanwhile, the biogas program by a non-government organization utilizes a semi-commercial approach; collaborating with multiple stakeholders (governments, local construction partner organizations, cooperatives, and private sectors-companies and banks); and has standardized training and after-sale services. Within those biogas programs, there are multiple barriers along the supply chain process of biodigester dissemination. These barriers relate to the governance aspect of biogas programs. Fragmented governance affected the capability of each program to tackle barriers in biogas digester dissemination. Besides, heavy subsidy on LPG by the government reduced attraction to biogas. This study shows technology adoption barriers beyond the user/individual aspects. It shows interaction among different factors such as policy, the governance of technology transfer, technical production issues, and socio-cultural problems.
\end{abstract}

Keywords Bioenergy $\cdot$ Biogas $\cdot$ Governance $\cdot$ Program $\cdot$ Fragmentation

\begin{tabular}{|c|c|}
\hline \multicolumn{2}{|c|}{ Abbreviations } \\
\hline BIRU & $\begin{array}{l}\text { : Biogas Rumah or House's biogas project by } \\
\text { Hivos and YRE }\end{array}$ \\
\hline $\mathrm{CO}_{2}$ & : Carbon dioxide \\
\hline $\mathrm{CPO}$ & $\begin{array}{l}\text { : Construction partner organization at the local } \\
\text { level }\end{array}$ \\
\hline CSR & : Corporate social responsibility \\
\hline DRPM & $\begin{array}{l}\text { : Directorate of Research and Community } \\
\text { Development at University of Indonesia }\end{array}$ \\
\hline Hivos & : An international cooperation organization \\
\hline KPSBU & $\begin{array}{l}\text { : A dairy farmer cooperative in North Bandung, } \\
\text { West Java }\end{array}$ \\
\hline
\end{tabular}

Ibnu Budiman

ibnu.budiman@wur.nl

1 Environmental Policy Group, Wageningen University, 6700 AK Wageningen, The Netherlands

2 ASEAN Center for Energy, Jl. H. R. Rasuna Said No.Kav 7-8, Jakarta 12950, Indonesia
LPG : Liquefied petroleum gas

MA : Ministry of Agriculture

MDP : Ministry of Development Planning

M-E : Monitoring and evaluation

MEF : Ministry of Environment and Forestry

MEMR : Ministry of Energy and Mineral Resources

NAMA : Nationally Appropriate Mitigation Actions

NGO : Non-Government Organization

NVivo : A qualitative data analysis computer software package

Proklim : Climate village project, by the MEF

RE : Renewable energy

RERC : Renewable energy research center at the MEMR

SAF : Special allocation fund, state budget

SWEN : A biogas digester producer company 
UPPO : Processing unit of organic fertilizer, a project by the MA

YRE : Yayasan Rumah Energi or Home Energy Foundation

\section{Introduction}

Since the 2000s, the global south countries such as Indonesia have shown rapid economic growth that guided to high dependence on oil and gas for energy [1]. The use of fossil fuel has been significantly increasing Greenhouse Gasses emissions [2]. Regarding energy for cooking, liquefied petroleum gas (LPG) and firewood are the dominant energy sources in Indonesia [3]. 31.3\% of the population in rural areas still use firewood as the main cooking fuel. This contributes to environmental and health issues such as forest degradation, carbon emission, breathing disorders, and mortality. Meanwhile, LPG is utilized by $63 \%$ of the population in rural areas and this starts to be a new source of greenhouse gas emissions in the countryside [2, 4]. To support energy transition to renewable energy, biogas is seen as a clean source of energy that can be developed further to tackle environmental and health problems caused by LPG and firewood use [5]. In Indonesia, small-medium scale biogas with different technologies such as at the household level has been introduced formally since the 2000s [6]. However, there is fragmentation within the governance of the small-medium scale biogas programs in Indonesia that has mixed impacts on the programs [1,7]. The problem of fragmented governance, with weak institutions, makes programs on technological dissemination/diffusion activities are vulnerable to issues that hinder transition pathways to low carbon energy through the biogas sector [8, 9]. For example, lack of cooperation between institutions that have biogas programs made them having overlapping programs in the same location, while other locations have no access to the biogas digester [10, 11].

The governance problems may connect to the dissemination issues. By 2015, the total number of biogas digesters in Indonesia only accounts for $1.24 \%$ of households [4]. This makes biogas is hence much less common than LPG and firewood as other cooking fuels [12]. This research aims to identify systemic barriers to biodigester dissemination by analyzing the landscape of biogas governance in Indonesia, its fragmentation, and its consequences to barriers to biodigester dissemination. Previous studies identified some dissemination barriers constraining fuel substitution with biogas, from the bureaucratic process, the time-consuming process of feedstock, social acceptance, different priority, monitoring practices, and poor technological maintenance [7, 13-15]. Yet it was presented as scattered issues. This study identifies intercorrelation among those barriers and with the landscape of biogas governance. The intended output of this study is to provide suggestions to policymakers and development practitioners to improve policy, governance, and practices of biogas programs.

\section{Framework and methods}

The conceptual framework of this research utilizes the theory of fragmentation as a framework that features specific aspects within the biogas regime. This theory argues about the governance architectures of the climate-energy regime that are seldom fully interconnected and integrated, and thus, fragmented. In the global climate-energy governance architecture, this fragmentation relates to a lack of interlinkages between institutions, for both state and non-state actors [16]. Such fragmentation is not necessarily problematic and the 'diversity' of institutions within regimes is something that can be managed. This research utilizes the indicators within the theory, which are the coordination and cooperation dynamics.

The theory of fragmentation is linked to policy/governance as a framework that features specific aspects within the biogas regime in Indonesia. The regime of small-medium biogas in Indonesia experienced conflictive and cooperative fragmentation from 2009 to 2017, where there had been conflict and cooperation among different biogas programs [7]. This study analyses how those dynamics affected the capability of each biogas program in tackling barriers in the dissemination of biodigester.

This study utilizes inductive reasoning where the logical thinking or analysis in the paper involves forming generalizations based on specific incidents/findings found from data collection. The coordination, cooperation, and interaction dynamics among biogas programs were cross analyzed with specific barriers to biodigester dissemination, in the value and supply chain of the biodigester. First, coordination, cooperation, and interaction dynamics among biogas programs were identified. Afterward, series of analyses to connect the interaction dynamics with multiple barriers in biodigester dissemination were done to complete data analysis.

For methodology, this research utilized qualitative data analysis. This method involved multiple forms of qualitative data that consist of interviews, document reviews (including policy and project reports), and series of analyses concerning the conceptual framework (Fig. 1). Twenty-two semistructured interviews were conducted during the fieldwork in 2018. Each interview took about $1 \mathrm{~h}$ and was done in the office of respective institutions. Besides, this study also included some quantitative data for the number of biodigester dissemination. 

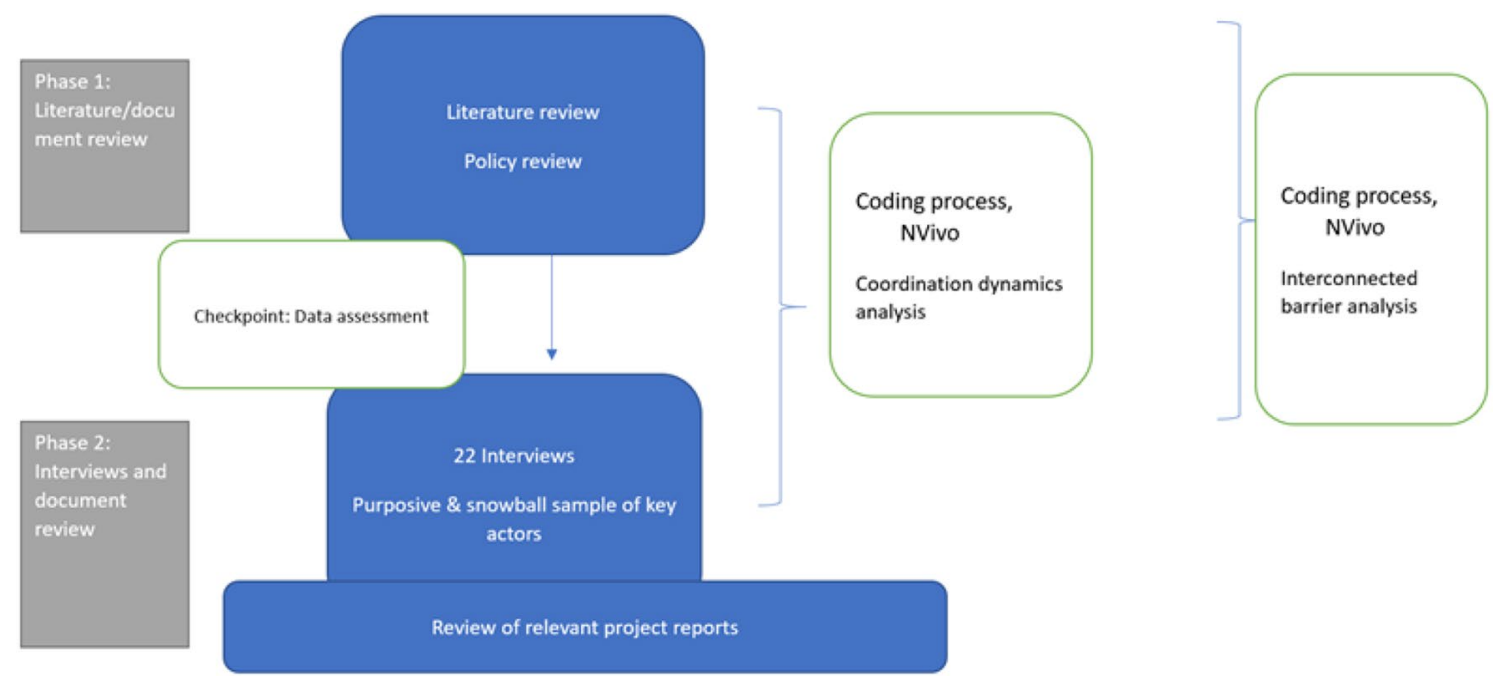

Fig. 1 Data collection and analysis

The focus is on four institutions that have biogas programs, such as Hivos (Non-Government OrganizationNGO), Ministry of Energy and Mineral Resources (MEMR), Ministry of Agriculture (MA), and Ministry of Environment and Forestry (MEF). Sources from representatives of various stakeholders were chosen in those different institutions, to balance the information. Purposive and snowball sampling techniques were used in selecting representatives from the four institutions that have biogas programs. Besides, several stakeholders that are related to biogas programs in the four institutions were also interviewed, to verify the information. Minimum two sources for representatives in the four institutions and their related stakeholders were chosen to minimize bias/subjectivity in collected data and information.

After data collection, all data were organized to prepare the structure of the evidence, based on the conceptual framework and its indicators. Depending on the nature of the data, they were transcribed (in case of interviews), scanned (in case of document and literature review), or typed up (in case of other field notes). Later, for a more detailed analysis, a coding process was undertaken. The first coding session was done on the interview transcripts, policy documents, and program/project reports to analyze governance arrangements from each biogas program and its institutions. Afterward, the second round of coding was done to analyze the coordination dynamics and a third coding round then analyzed the interconnected barrier analysis.

\section{Result}

The existence of biogas programs is triggered by national policies in Indonesia. The existence appears in the implementation of various biogas programs in different ministries and non-state institutions. The explanation in this chapter aims to provide an overview of biogas-related policies and programs, their governance arrangements, and the barriers to biodigester dissemination.

This study found that there are only two general policies related specifically to biogas, which are energy mix and national climate change mitigation or NAMA. ${ }^{1}$ From those policies, the government utilizes voluntary biogas programs by providing grants from the government budget, foreign development aid, and funding from non-governmental bodies. The biogas program targeted the households and small community groups such as farmers groups and forest communities. Two types of governance arrangements are found in scattered biogas programs; (1) decentralized governance as the programs that come from the government bodies, and (2) interactive governance, as the programs led by nonstate actors in partnership with various stakeholders. These biogas programs have multiple dissemination barriers that are related to their governance arrangements (see "Fragmentation and biogas dissemination barriers").

\section{Biogas-related regulations}

Two national regulations are relevant to biogas dissemination in Indonesia, which are; (1) energy mix target (legitimized in 2006 and renewed in 2017) and (2) the national climate change mitigation plan for climate change or NAMA (legitimized in 2011). Both regulations are related to the emergence of biogas programs.

\footnotetext{
1 MEMR. (2016). MRV FRAMEWORK FOR ENERGY COMPONENT OF RAN-GRK. http://www.lowcarbondev-support.org/-/../ FIRM-Indonesia-MRV-framework.ashx.
} 
Table 1 Biogas in the programs on different directorates in the MA (Source: Author's interviews)

\begin{tabular}{lll}
\hline The institution within the MA & Program & Year \\
\hline $\begin{array}{l}\text { Directorate of processing and marketing agriculture } \\
\text { products }\end{array}$ & $\begin{array}{l}\text { Batamas (Biogas from communities' } \\
\text { livestock) }\end{array}$ & 2007-2014 \\
Directorate of livestock & $\begin{array}{l}\text { Zero-waste livestock: biogas, compost, } \\
\text { liquid fertilizer }\end{array}$ & 2010-2017 \\
Directorate of agriculture infrastructure & UPPO (Organic fertilizer processing & 2008-now \\
& unit) & \\
\hline
\end{tabular}

Energy mix target is part of national energy policy, that is formulated in national energy plan ${ }^{2}$ and local energy plan. Energy mix has the target of $10 \%$ of bioenergy by 2025 . Within those plans, there is the target for biogas dissemination that combines all scales of biogas, from large industrial scale to household scale. Besides, biogas for the household is also mentioned under the planning for small-scale energy [16]. Yet, still, there is no specific target or number for household biogas and medium-scale biogas. Besides achieving the energy mix target, the Ministry of Energy and Mineral Resources (MEMR) has a biogas program that also aims to reduce the cost of subsidies for kerosene and LPG.

Meanwhile, NAMA is targeted to achieve the 26\% ( 0.7 $\mathrm{GtCO}_{2} \mathrm{e}$ ) emissions reduction target by 2020 . Under the sector of agriculture and energy, biogas is included as one of the action plans to be done by the Ministry of Agriculture (MA), Ministry of Energy and Mineral Resources (MEMR), and Ministry of Environment and Forestry (MEF) as implementing agencies. The national government estimated that biogas usage will reduce by 1.01 million tons of $\mathrm{CO}_{2} \mathrm{e}(0.001 \%)$. From this target, NAMA expected 0.13 million $\mathrm{tCO}_{2} \mathrm{e}$ to come from 31,400 units of household biogas digesters with a volume of 5-6 $\mathrm{m}^{3}$ (B. MEMR, 2016). One biogas unit of $6 \mathrm{~m}^{3}$ capacity is estimated to reduce 3.2 tons $\mathrm{CO}_{2} /$ year according to Gold Standard [17]. The biogas digesters are planned to be distributed to farmers households that own sufficient livestock and use fossil fuel (LPG) or non-renewable biomass (firewood) as their cooking fuel. In the NAMA, biogas programs are only counted if it has the clear target and can be monitored, reported and verified, such as biogas programs from the MEMR and the MA.

Both regulations, energy mix target and NAMA are connected to the establishment of various biogas programs and projects in different institutions, to achieve the energy mix and emission reduction targets. Beyond energy mix target and NAMA, different motivations and problem backgrounds are also found in the biogas programs in other ministries, such as the topics of waste management and forest conservation. The Ministry of Development Planning (MDP)

\footnotetext{
${ }^{2}$ Government of Indonesia [GoI]. (2017). Rencana Umum Energi
} Nasional. (Lampiran II Perpres No 22 Tahun 2017). recognized that the bioenergy programs, including biogas, are scattered in different ministries out of the MEMR, such as the Ministry of Agriculture (MA), and the Ministry of Environment and Forestry (MEF). In the MA, the motivation is to manage animal waste from the beef self-sufficiency program, for converting cattle manures to be compost and biogas. In the MEF, the biogas program helps them with forest conservation, forest community development, and emission reduction. The biogas digester is introduced to prevent forest people from using firewood. These different motivations cause the fragmentation of biogas-related policy results in scattered biogas programs in different institutions.

\section{Biogas programs from different institutions}

This section focuses on the biogas programs from four selected institutions, which are three government bodies (MEMR, MA, and MEF) and Hivos as non-government bodies (Tables 1, 2, 3). These institutions have the main small-medium scale biogas programs in Indonesia. In this section, general characteristics and output from biogas programs in four selected institutions are provided, to construct the analysis of governance architecture and the fragmentation in the following chapter. This section is structured with an explanation per institution, then per program owned by the institution and its characteristics that consist of the general description of programs, key changes, partners for cooperation, and the dynamics within the program and/or the institution. Table 4 shows the summary of the characteristics and output of those biogas programs.

Besides the biogas programs from four selected institutions in this research, this research found that there are still

Table 2 Biogas programs in the MEMR (Source: Author's interviews)

\begin{tabular}{lll}
\hline $\begin{array}{l}\text { The institution within the } \\
\text { MEMR }\end{array}$ & Program & Year \\
\hline Directorate of bioenergy & $\begin{array}{c}\text { Household biogas program } \\
\text { Communal biogas program }\end{array}$ & $\begin{array}{c}2011-\text { now } \\
2011-\text { now }\end{array}$ \\
& $\begin{array}{c}\text { BIRU partnership; Biogas } \\
\text { for household }\end{array}$ & $2009-2015$ \\
& $\begin{array}{c}\text { Center of information and } \\
\text { demonstration of biogas }\end{array}$ & 2005-2017 \\
\hline
\end{tabular}


Table 3 Biogas-related programs in the MEF (Source: Author's interviews)

\begin{tabular}{lll}
\hline The institution within the MEF & Program & Year \\
\hline $\begin{array}{l}\text { The deputy assistant of management of climate change impact } \\
\text { (under the ME, before the ministry was merged) }\end{array}$ & $\begin{array}{c}\text { Biogas for low carbon } \\
\text { technology }\end{array}$ & 2008-2010 \\
The directorate of climate change & $\begin{array}{c}\text { Proklim (Climate vil- } \\
\text { lage) }\end{array}$ & 2010-now \\
The directorate of conservation & $\begin{array}{c}\text { Community develop- } \\
\text { ment }\end{array}$ & 2010-now \\
& & \\
\hline
\end{tabular}

many other biogas programs coming from several other ministries such as the Ministry of Public Works and Housing, Ministry of Villages, Development of Underdeveloped Regions, and Transmigration; Ministry of Women Empowerment and Children Protection, and Ministry of Cooperatives and Small-Medium Enterprises. Some local governments also have their biogas programs. This fact implies that the biogas programs are more fragmented beyond the scope of this research and the challenges for coordination within the architecture are more difficult.

Biogas programs are scattered in different ministries (also scattered in different directorates or sub-institution within the ministry), such as the Ministry of Agriculture (MA), the Ministry of Energy and Mineral Resources (MEMR), and the Ministry of Environment and Forestry (MEF); and in Hivos. The ministries have a wide range of problem backgrounds to justify their biogas programs, which are related to policies of the energy mix, climate change mitigation, food security, and forest conservation. Almost all those governmental biogas programs relatively have the same characteristics; using the grant approach, cooperate with local government and vendors, and do not have proper training and monitoring-evaluation scheme. However, there is no effective coordination among these government programs that result in a lack of cooperation to achieve the bigger target for renewable energy dissemination and emission reduction. Meanwhile, the Hivos program called BIRU utilizes a semi-commercial approach; collaborates with multiple stakeholders such as government bodies, construction partner organizations, cooperatives, and private sectors (companies and banks); and has standardized training and after-sale services. The fragmentation triggers innovation in different biogas programs.

\section{Fragmentation and biogas dissemination barriers}

This section analyzes how fragmented biogas programs above related to multiple barriers to biodigester dissemination, especially on governance barriers. Table 5 shows the list of barriers showed within the supply chain process of biogas dissemination (from the production of biogas, consumption by the users related to culture and knowledge issues on the community), and program-related barriers, link to funding, management, governance, and policy issues. These barriers are relevant to most of the biogas programs above.

The Ministry of Agriculture (MA) mentioned that the Ministry of Development Planning (MDP) targeted to install 300,000 small biogas digesters (size of $6 \mathrm{~m}^{3}$ ). The MDP divided the target into several ministries, including the MA. The MDP even said that the government needs millions of digesters to be disseminated. But, the target number of disseminations is sometimes based on the budget available from the Ministry of Finance. In 2006, the National energy policy included biogas as part of energy development planning. However, the implementation of biogas development is not significant. Although the potential is abundant, there were only about 30,000 digesters of various sizes that have been installed [14]. Even, not all of it has been utilized.

The data of biodigester dissemination number come from the MEMR. The MEMR collected data from other biogas programs such as BIRU, and SWEN who worked as the third party to various biogas projects by ministries, the local governments, and non-state actors. The data ${ }^{3}$ showed that there had been 36,032 biogas digesters from those different biogas programs all over Indonesia till 2017. This data also originated from the grant record and proposal disbursement. The validity of these data was limited because of the absence of comprehensive physical monitoring and evaluation (M\&E). The detail M\&E could not be implemented because the local energy agency at the provincial level had limited resources of personnel and funding to check all biogas in their wide range of areas. In some areas such as Java, this task was helped by the coordination from the farmers' group, in partnership with YRE (Home Energy Foundation) and Hivos who had good institutional management. The Directorate of Bioenergy mentioned that they plan to have detail M\&E for the whole area to check biogas condition. Another limitation for data validity was because the MEMR could not collect data from the biogas program in other ministries such as the MEF and the MA.

\footnotetext{
${ }^{3}$ Kementrian ESDM [ESDM]. (2018). Realisasi program biogas. Directorate of bioenergy.
} 


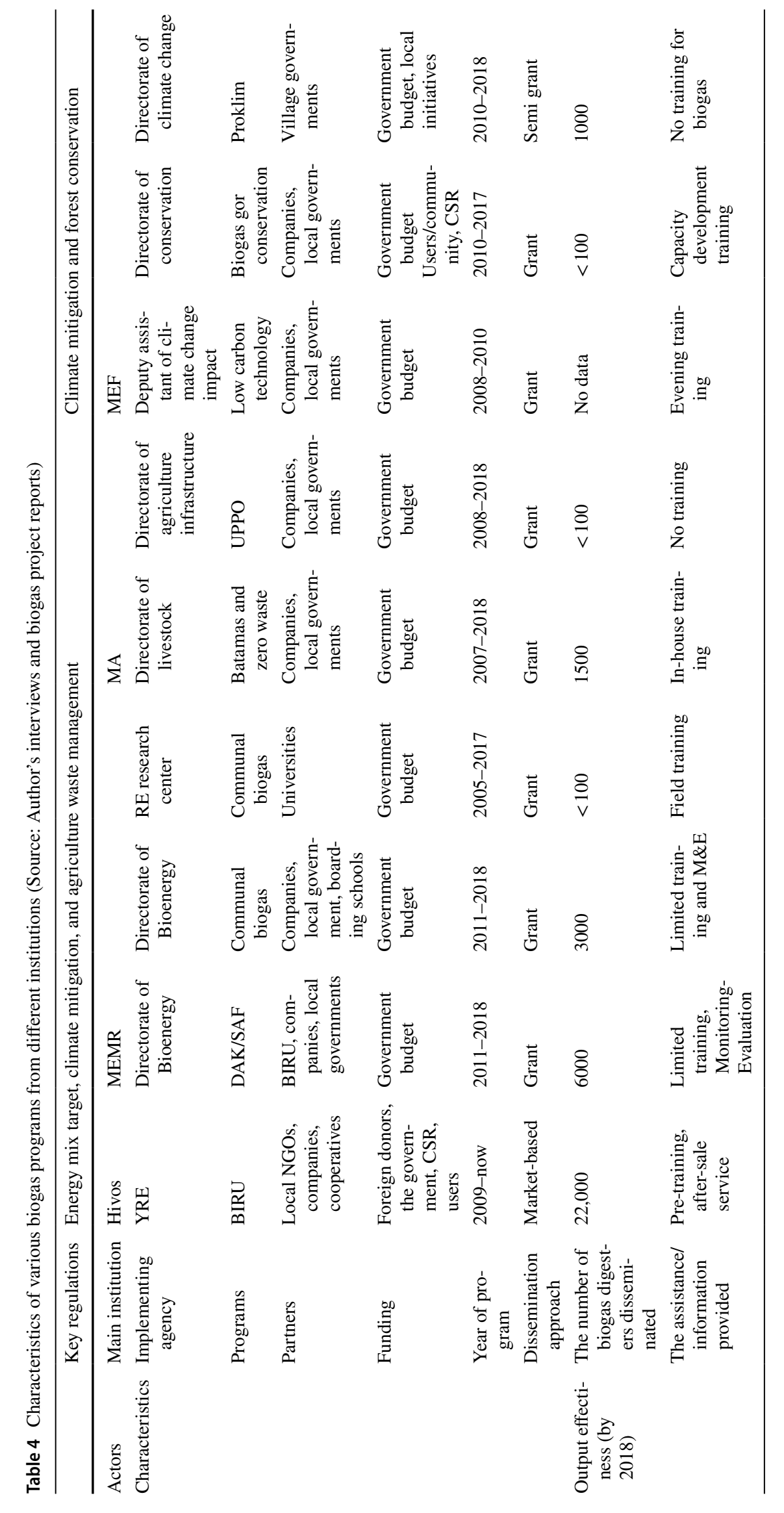




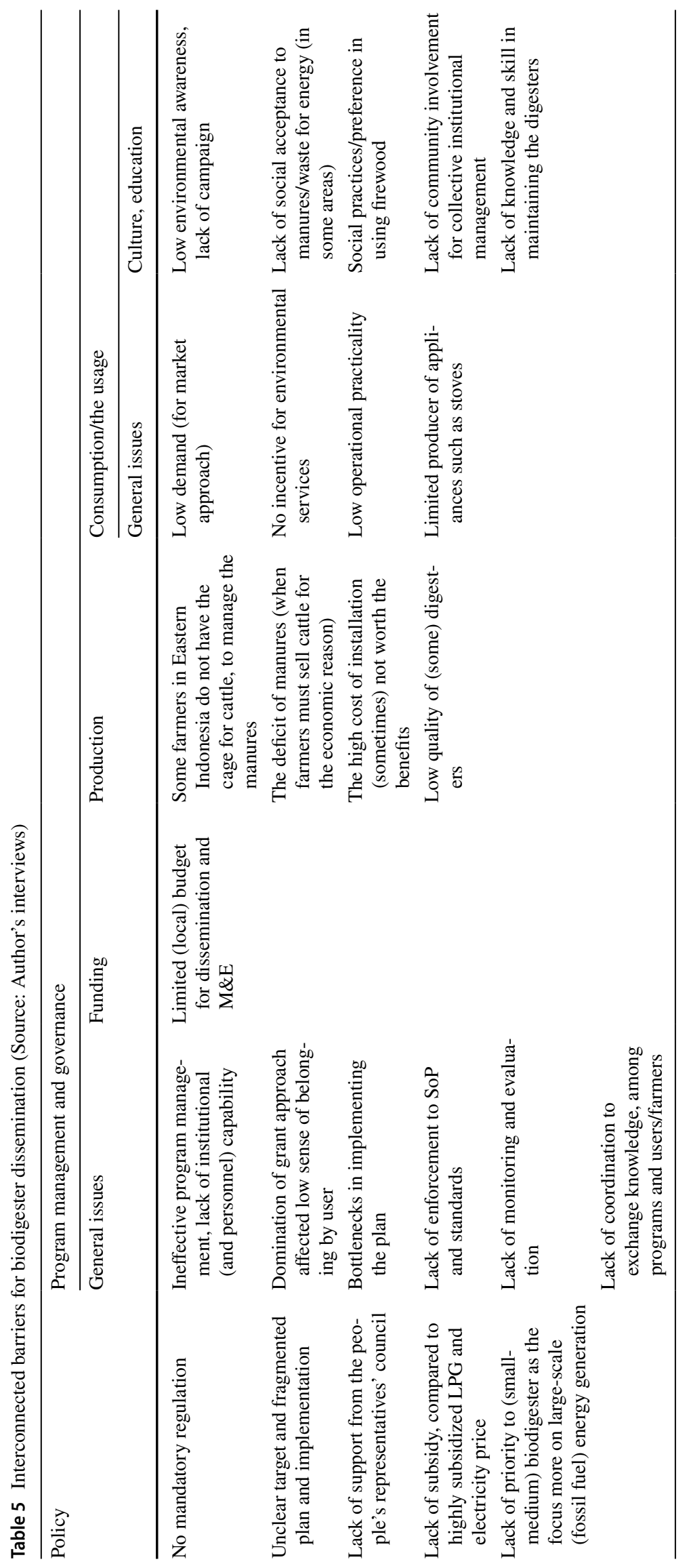


There are still many biogas programs from the Ministry of Villages, Development of Underdeveloped Regions, and Transmigration; the Ministry of Social, the Ministry of Agriculture, and the Ministry of Environment and Forestry, (MEMR interview, 6 June 2018, translated from Bahasa).

So, the MEMR had limited reliability on data of biodigester dissemination because not all programs were recorded by the MEMR.

Some renewable energy-related policies from the MDP, the MEMR, NAMA, and BIRU had uncleared and different targets for biogas dissemination. There was no coordinated target. It brought scattered planning and implementation that results in fragmented programs. Various biogas programs above show that there is fragmentation in the implementation of biogas policy. This fragmented implementation affected the interaction between multiple barriers to biodigester dissemination. The fragmented biogas programs affected the capability of each program to tackle multiple barriers in biogas dissemination.

\section{Production barriers}

An important aspect of the production side is the technological issue. Many stakeholders mentioned that the issue in the biogas production was the cost of technological installation. The cost is relatively high for the farmers. The Ministry of Environment and Forestry (MEF) mentioned that the cost should be covered together by the government, NGOs, donors, and companies CSR. Meanwhile, BIRU argued that the high cost reflects the high quality of digesters that could provide multiple benefits. Good quality biodigester technology provides customer satisfaction for the user. There is a need to have a consensus about the appropriate cost. The cost problem relates to practicality issues in biogas technology. The MA said that the unavailability of practical technology like portable digester or portable media for transporting gas is a barrier to biodigester dissemination. Nevertheless, PT SWEN claimed that they already have that technology. But, the problem was some government institutions did not want to use it due to the budget constraint.

Another problem with the quality of biodigester is the bad performance by some construction partner organizations (CPOs) in installing biodigester. Some CPO does not obey the guideline for constructing good quality biodigester. It resulted in the low-quality technology used by the user. This issue brought negative public perception toward biodigester. Besides, the lack of producers for the appliances of biodigesters such as stoves and pipes became another barrier to biogas production.

In the farming regions, biodigester dissemination and biogas production are limited by the farming behavior in some regions like East Indonesia, in which the livestock is not caged, but is spread in the meadow or pasture. This behavior makes the farmers have difficulty collecting the manure for biogas raw material. For farmers who have the cage for their cattle, the issue is their behavior to sell the cattle when they need quick income for the family financial reason. This practice reduces the stock of manures for biodigester operation, so the biodigester cannot be used temporarily until the farmers have new cattle.

The Directorate of Bioenergy MEMR stated that biodigester dissemination cannot be massive because it only works for the livestock farming regions. However, PT SWEN rejected the MEMR argument about the limited applicability of biodigester:

We have produced biodigesters for non-agriculture wastes, such as for domestic waste and human manures. We also actively promoted the products to the government and private sectors.

\section{Low market demand}

The issues on the production side of biodigester affect the market demand from the user. People found that biodigester is not practical to use because it requires a lot of effort to collect the manures, put it into the digester, and mix it with water, manually. So, many people rejected to commit to that timely efforts-to generate energy. This rejection influenced low demand from the community to biodigester. This barrier became the obstacle to promote biodigester.

The consumption barrier relates to social issues in the community. The low demand was also influenced by the socio-economic acceptance of people to biodigester. The MEF found that biodigester was not interesting for the community due to the community mindset about the manures. For instance, in Aceh, people are disgusted with the manures and they prefer to keep using the firewood. This choice was also due to the preference of local people who like the flavor of food that is cooked using firewoodstove. People's preferences and behaviors are affected by their social practices that lack environmental awareness about biogas benefits. Some cases showed that the farmers stopped using biodigester when their economic condition increases and they back to use LPG. Many people still require socio-economic incentives to use biogas.

The renewable energy research center (RERC) in the MEMR argued that community involvement is important for biogas digester dissemination. This involvement triggers the community's need to run the biodigesters. This involvement can be managed through good institutional management by running the partnership in biogas programs. This example could be seen in the BIRU program that collaborates with the farmers' groups and exchanges 


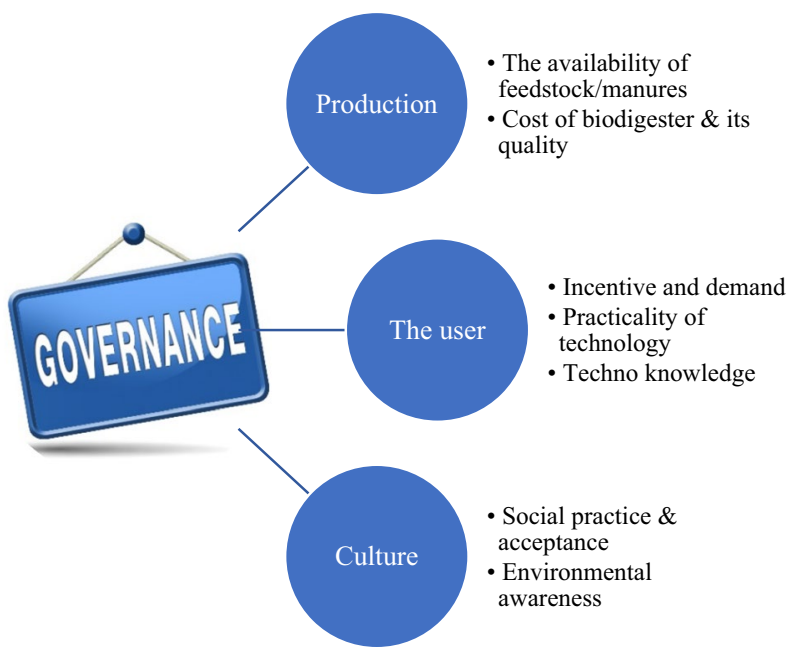

Fig. 2 Linkages among the topic of barriers to biodigester dissemination

knowledge about the know-how of biodigester. However, this practice was rarely found in other biogas programs that caused the user could not deal with the socio-technical problem in using biodigester. Some regions also have no farmers group to support knowledge exchange about biogas.

\section{Governance barriers}

Barriers to production, consumption and social issues of biodigester relate to the governance aspect of biogas programs. Figure 2 shows the connection between those different topics of barriers to biodigester dissemination.

Barriers on the production and consumption side are influenced by the governance problem within the biogas programs. Failure in planning and implementation of the program led to issues on program management in the field that connects to the users. The MA found that there were only a few members of farmer groups who had an understanding of biogas use, not all of them. It made the maintenance standards of biodigester were not consistently implemented in the program. This issue caused technical problems on some biodigesters. Meanwhile, the government only conducted monitoring and evaluation (M\&E) about 1-2 times a year, based on the problem report from the user after installation. This effort was limited by resources such as time and the budget to cover a wide range of areas all over the country. As a result, many biodigesters are left broken by the user and it affects the public image of the technology. This issue influences the social acceptance of other people toward biodigester [3].

Meanwhile, the RERC in the MEMR said that the Government of Indonesia has the budget for the biogas program.
But the people's representative council also often did not approve biogas programs from the ministries in the budget planning. This barrier to funding hampered the implementation of biogas programs.

The MEF mentioned another governance issue in the biogas program which is the grant approach by the government that provided the full subsidy of biodigester to people. Although it made people content to get free biodigester, the problem is that the grant also made them have a low sense of belonging to the digester technology. Many grantees did not take care of their biodigester. For example, the behavior of selling cattle due to economic reasons made digester goes useless. This problem is related to a low sense of ownership by the community to the free digesters. To tackle this barrier, BIRU tried to find consensus between the grant and the commercial approach by reducing the amount of subsidy. Yet, the result of this effort was still limited in some biogas programs by the local governments.

Another governance issue was lack of coordination among biogas programs to exchange information about; best production practices, creating demand from the consumer, program management and approach, and effective $M \& E$.

Lack of coordination among biogas programs is caused by limited priority by the ministries to the program itself, so they did not put effort into the coordination, (MDP interview, 4 June 2018).

The Ministry of Development Planning (MDP) mentioned that biogas alone is not the priority in national energy planning. Biogas target could not be separated from other bioenergy types. In the roadmap for the bioenergy plan, the priority is given more to biomass, bio-solar, bioethanol, and biodiesel. This plan was projected to be done in collaboration with energy companies such as Pertamina, PT $\mathrm{PN}, \mathrm{Medco}$, and Agri industries such as cassava, sugarcane, palm oil. There were many bottlenecks for the bioenergy implementation, such as difficulty in providing good fiscal or pricing that attracts private sectors and non-fiscal incentives to have support from the local government. The government currently focuses to solve it and thus (small-medium scale) biogas did not get serious attention. This issue is a policy barrier to biodigester dissemination.

Indonesian renewable energy development (priority) and utilization strategy mentioned two focuses about bioenergy; (1) development of bioenergy power plant including agricultural waste and municipal solid waste to provide electricity as well as to improve the environment; (2) utilization of biofuel for substitution of fuel oil [18]. The MEMR hence supported private sectors such as the palm oil and tofu/bean curd industry to develop a biogas power plant. That strategy did not mention the small and medium-scale biogas programs. The MDP said that solar and biogas are less prioritized because the result is small, despite the potential is big. 
Less priority to biogas affected the budgeting in the ministries. The Directorate of Renewable Energy in the Ministry of Energy and Mineral Resources mentioned that since 2012, they had no funding from the national budget to continue the household biogas program. The budget was cut because the national government wanted to focus on communal biogas programs and other electricity programs. The MEMR argued that household biogas already has mature technology, so they let the local government continue it. Alternatively, the MEMR utilizes the local government budget and special allocation fund to fund the household biogas program.

In the bigger context of renewable energy (RE), the government priority was more for the large-scale potential such as geothermal that has technology availability, and able to produce large-scale electricity. This decision was taken by the government to achieve the target of emission reduction and electrification ratio. Meanwhile, the MEMR realized that the renewable energy target in national energy policy will be difficult to be achieved. The Ministry of Coordinator of Maritimes argued that the attention to RE is still relatively low because the government is still more focused on conventional energy such as fossil fuel.

These governance issues became a barrier for the coordination among the ministries, to resolve problems on the production, consumption, and social issues on biodigester dissemination. Therefore, fragmented government biogas programs remain ineffective without sufficient coordination.

\section{Discussion and conclusion}

Biogas programs in Indonesia are fragmented different ministries (the Ministry of Agriculture/MA, the Ministry of Energy and Mineral Resources/MEMR, and the Ministry of Environment and Forestry/MEF) and NGOs. The fragmentation was caused by a diversity of policy drivers. In the MA, the motivation is to improve the management of agriculture waste through managing cattle manures for compost and biogas. For the MEMR, the biogas program aims to reduce the cost of subsidy for kerosene and LPG and to achieve the energy mix target. In the MEF, the biogas program helps forest conservation, forest community development, and emission reduction. These different motivations and problem backgrounds show that the biogas programs in those ministries relate to several policies such as energy mix target, NAMA (National Mitigation Action), waste management, and forest conservation. It shows that the fragmentation of biogas-related policy is wide, and this increases the difficulty for coordination among biogas programs.

Almost each biogas program in respective ministries stands alone. Three types of governance arrangements are found in those fragmented biogas programs; (1) (de)centralized governance as the programs that come from the ministries (MEMR, MA, MEF) and coordinated with local governments, and (2) interactive governance, as the programs led by non-state actors in partnership with various stakeholders, including the government. (3) Few government programs tried to combine decentralized arrangements with a limited degree of interaction with non-state actors. These governance arrangements construct the biogas governance architecture in Indonesia. The challenge for that architecture is to find the strategy to harmonize different biogas programs with different arrangements, in tackling dissemination barriers.

Most governmental biogas programs have decentralized governance arrangement, with the following characteristics; scattered in different directorates or sub-institution within the ministry, using the grant approach, cooperate with local government and vendor, and do not have proper training and M\&E. Meanwhile, the NGO program with interactive arrangement utilizes semi-commercial approach; collaborates with multiple government bodies, construction partner organizations, cooperatives, and private sectors (companies and banks); and has standardized training and after-sale services.

Within the biogas programs, there are multiple barriers (including socio-cultural issues and governance aspects) along the supply chain process of biodigester dissemination (from production to consumption/usage). These barriers are relevant to most of the biogas programs, but this study found that the interactive arrangement works better in tackling dissemination barriers. Lack of coordination and cooperation among the biogas programs affected the capability of each program to tackle barriers in biogas digester dissemination. The following points show the interconnection between production and consumption/usage barriers to the governance aspect of biogas programs:

- Lack of technoscientific knowledge on the users is influenced by failure on planning and implementation of training and M\&E;

- Lack of coordination among biogas programs to exchange information on best practices in implementation reduces the opportunity to construct good quality biodigester installation, to create demand from consumer/user, and to have effective program management and approach;

- Lack of demand is influenced by the full subsidy approach by the government.

The novelty of this study is showing the complexity of barriers to biogas technology adoption. It goes beyond the user/farm(er) aspects and involves interaction with different factors such as policy, the governance of technology transfer, technical production issues, and socio-cultural problems. This makes biogas use not widespread in Indonesia, but it is 
widespread in other countries such as China, Thailand, and India, because they deal with that problem.

On policy aspects, the MEMR in Indonesia does not apply and enforce strong policy instruments to promote and disseminating biogas technology. The ministry created the biogas program to reduce the cost of subsidy for LPG and to support their energy mix target. LPG is still heavily subsidized by the government as the primary source of cooking fuel/energy [19]. This makes the demand for biogas remains low. This situation is different compared to other countries. For example, Thailand has set out to increase the use of alternative energy consumption including biogas in all sectors due to the national policy in alternative energy development [20]. This contributed to increasing biogas production in the country and made Thailand one of the four countries with the highest biogas production in the world.

The policy is related to the governance aspect. The fragmented biogas programs across institutions and the coordination issues in Indonesia reduced the effectiveness of dissemination of biogas technology. The opposite situation was found in China. Although the development of household biogas in rural China also involves various policy instruments and governance arrangements (directive and guiding policies, economic-inspiring policies, research policies, market policies, and other constructive policies), these policies and arrangements are more integrated. Every policy was gradually issued by the government. In addition, the National People's Congress also enacted five relevant laws: The Agricultural Law, Renewable Energy Law, Animal Husbandry Law, Energy Conservation Law, and the Act on the Development of Circular Economy. Relational rules and regulations in different sectors and at levels were also formed in response to the national policies and laws, whilst the technology standard within projects was also more established and enforced. Feng et al. [21] found that those series of constructive policies were gradually combined with policies on renewable energy development and later with the policy on climate. This contributed to double the number of household biogas digesters and annual biogas output in China, up to 40 million households using biogas digesters. China has succeeded in integrating multiple policies and arrangements to increase the output of biogas development.

Another governance issue in Indonesian biogas is the dominant dissemination strategy using grant approach that made user/farmers/households tend to prefer provision of biogas technology for free. Many households do not want to buy it because they prefer to wait for free provision from the government or development/NGO projects. This pattern led to temporary and pseudo adopter behavior where users adopt technology is not because they want it to support their energy use, but only to gain free benefits from development programs [22]. In comparison, India also had the same problem. But then, many efforts are put to reduce the biogas system installation cost barrier by providing low-cost credits like interest-free loans or subsidized loans [23, 24]. This is slowly changing the adopter behavior of the biogas users.

Further research is required on more comprehensive analysis on complex (social) system and systemic barriers) to biogas technology adoption. Tools such as system dynamics ${ }^{4}$ can be used to investigate whether policy and governance are a center to the systemic barriers of technology transfer.

\section{Recommendation}

To improve the capability of each biogas program to tackle barriers, two types (short term and long term) of recommendation are provided. Here are some suggestions for the short term:

- To enforce regulation on the use of biogas through reducing the subsidy for LPG, particularly on farming regions that have the potential to generate biogas.

- To create a policy framework of an integrated biogas national plan that combines different targets from the energy mix, NAMA, BIRU, and other related policies.

- To maintain the distribution of power in biogas governance architecture, in different ministries such as the MA, the MEF, and other related ministries, to implement biogas programs.

- To formulate clear allocation of tasks and functions for different institutions in achieving the common target and plan for biogas programs.

After the short-term recommendations applied, the stakeholders are expected to implement these long-term recommendations, as follow:

- To increase the degree of partnership on the planning and implementation among the program, using integrated topics like climate action, renewable energy, and rural development.

- To have (in)formal provisions to support coordination and cooperation among organizations across administrative levels and sectors.

- To involve local institutions more actively in the creation of biogas-related institutions/programs.

\footnotetext{
${ }^{4}$ An example of this study was done in Vietnam [25] but only focused on the user/farmer aspect, not involving non-user aspects.
} 
- To distribute institutionalized functions, responsibilities, authority, and finance across programs.

- To adjust the level of decentralization following the available personnel capability in term of knowledge.

- To develop social innovation at the community level [8].

These recommendations are also suitable to be implemented beyond the case of biogas governance and outside Indonesia. Those recommendations have broader applications in the field of environment and renewable energy policy and governance.

Acknowledgements Thanks to LPDP, Mattijs Smits, and Environmental Policy Group at WUR for supporting this study.

Open Access This article is licensed under a Creative Commons Attribution 4.0 International License, which permits use, sharing, adaptation, distribution and reproduction in any medium or format, as long as you give appropriate credit to the original author(s) and the source, provide a link to the Creative Commons licence, and indicate if changes were made. The images or other third party material in this article are included in the article's Creative Commons licence, unless indicated otherwise in a credit line to the material. If material is not included in the article's Creative Commons licence and your intended use is not permitted by statutory regulation or exceeds the permitted use, you will need to obtain permission directly from the copyright holder. To view a copy of this licence, visit http://creativecommons.org/licenses/by/4.0/.

\section{References}

1. Bond T, Templeton MR (2011) History and future of domestic biogas plants in the developing world. Energy Sustain Dev 15(4):347-354

2. Austin KG et al (2018) A review of land-based greenhouse gas flux estimates in Indonesia. Environ Res Lett 13(5):055003

3. Andadari RK, Mulder P, Rietveld P (2014) Energy poverty reduction by fuel switching. Impact evaluation of the LPG conversion program in Indonesia. Energy Policy 66:436-449

4. (2017) Persentase rumah tangga menurut provinsi dan bahan bakar utama untuk memasak tahun 2001-2007-2016. [Online] https://www.bps.go.id/statictable/2014/09/10/1364/persentaserumah-tangga-menurut-provinsi-dan-bahan-bakar-utama-untukmemasak-tahun-2001-2007-2016.html. Accessed 1 May 2018

5. Abdullah K (2002) Biomass energy potentials and utilization in Indonesia. Laboratory of energy and agricultural electrification, Department of Agricultural Engineering, IPB and Indonesian Renewable Energy Society [IRES], Bogor. http://stoves.bioen ergylists.org/stovesdoc/Fuels/msoB2D82.pdf

6. Budiman I (2020) The role of fixed-dome and floating drum biogas digester for energy security in Indonesia. Indones J Energy 3(2):83-93

7. Budiman I, Smits M (2020) How do configuration shifts in fragmented energy governance affect policy output? A case study of changing biogas regimes in Indonesia. Sustainability 12(4):1358

8. Smith J, Obidzinski K, Subarudi S, Suramenggala I (2003) Illegal logging, collusive corruption and fragmented governments in Kalimantan, Indonesia. Int For Rev 5(3):293-302
9. Smits M (2017) The new (fragmented) geography of carbon market mechanisms: governance challenges from Thailand and Vietnam. Glob Environ Polit 17(3):69-90

10. Budiman I (2018) Enabling community participation for social innovation in the energy sector. Indones J Energy 1(2):21-31

11. Putra ARS, Pedersen SM, Liu Z (2019) Biogas diffusion among small scale farmers in Indonesia: an application of duration analysis, (in English). Land Use Policy 86:399-405. https://doi.org/10. 1016/j.landusepol.2019.05.035

12. Bedi AS, Sparrow R, Tasciotti L (2017) The impact of a household biogas programme on energy use and expenditure in East Java. Energy Econ 68:66-76

13. Budiman I, Muthahhari R, Kaynak C, Reichwein F, Zhang W (2018) Multiple challenges and opportunities for biogas dissemination in Indonesia. Indones J Energy 1(2):46-60

14. Bößner S, Devisscher T, Suljada T, Ismail CJ, Sari A, Mondamina NW (2019) Barriers and opportunities to bioenergy transitions: an integrated, multi-level perspective analysis of biogas uptake in Bali. Biomass Bioenergy 122:457-465

15. Transrisk. Report on social discourse analyses and social network analyses. [Online]. https://europa.eu/capacity4dev/public-energy/ documents/transrisk-report-report-social-discourse-analyses-andsocial-network-analyses. Accessed 1 Jan 2018

16. Biermann F, Pattberg P, Van Asselt H, Zelli F (2009) The fragmentation of global governance architectures: A framework for analysis. Glob Environ Polit 9(4):14-40

17. Vorley B, Porras I, Amrein A (2015) The Indonesia Domestic Biogas Programme: can carbon financing promote sustainable agriculture? https://cgspace.cgiar.org/handle/10568/80386

18. Finahari I (2015) Indonesia renewable energy. Center for clean air policy. https://ccap.org/resource/indonesias-renewable-energypolicy/. Accessed 26 June 2018

19. Thoday K, Benjamin P, Gan M, Puzzolo E (2018) The Mega Conversion Program from kerosene to LPG in Indonesia: lessons learned and recommendations for future clean cooking energy expansion. Energy Sustain Dev 46:71-81

20. Damrongsak D, Chaichana C (2020) Biogas initiative from municipal solid waste in northern Thailand. Energy Rep 6:428-433

21. Feng Y, Guo Y, Yang G, Qin X, Song Z (2012) Household biogas development in rural China: on policy support and other macro sustainable conditions. Renew Sustain Energy Rev 16(8):5617-5624

22. Kiptot E, Hebinck P, Franzel S, Richards P (2007) Adopters, testers or pseudo-adopters? Dynamics of the use of improved tree fallows by farmers in western Kenya. Agric Syst 94(2):509-519

23. Mittal S, Ahlgren EO, Shukla PR (2018) Barriers to biogas dissemination in India: a review. Energy Policy 112:361-370. https:// doi.org/10.1016/j.enpol.2017.10.027

24. Ghosh P, Shah G, Sahota S, Singh L, Vijay VK (2020) Biogas production from waste: technical overview, progress, and challenges, chapter 7. In: Bioreactors, pp 89-104. https://doi.org/10. 1016/B978-0-12-821264-6.00007-3

25. Roubík H, Mazancová J, Rydval J, Kvasnička R (2020) Uncovering the dynamic complexity of the development of smallscale biogas technology through causal loops. Renew Energy 149:235-243

Publisher's Note Springer Nature remains neutral with regard to jurisdictional claims in published maps and institutional affiliations. 